\title{
Phytotoxic Lipophilic Metabolites Produced by Grapevine Strains of Lasiodiplodia Species in Brazil
}

\author{
Alessio Cimmino, ${ }^{\dagger}$ Tamara Cinelli, ${ }^{\dagger}$ Marco Masi, ${ }^{\dagger}$ Pierluigi Reveglia, ${ }^{\dagger}$ Marcondes Araujo da Silva, ${ }^{\S}$
} Laura Mugnai, ${ }^{*} \oplus$ Sami J. Michereff, ${ }^{\S}$ Giuseppe Surico, ${ }^{*}$ and Antonio Evidente ${ }^{\dagger \odot}$

\author{
${ }^{\dagger}$ Dipartimento di Scienze Chimiche, Università di Napoli Federico II, Complesso Universitario Monte S. Angelo, Via Cintia 4, 80126 \\ Napoli, Italy \\ ${ }^{\ddagger}$ Dipartimento di Scienze delle Produzioni Agroalimentari e dell’Ambiente, Sez. Patologia vegetale ed entomologia, Università di \\ Firenze, Piazzale delle Cascine 28, 50144 Firenze, Italy \\ ${ }^{\S}$ Department of Agronomy, Universidade Federal Rural de Pernambuco, 52171-900 Recife, Brazil
}

ABSTRACT: Phytotoxic metabolites produced in liquid culture by six species of Lasiodiplodia isolated in Brazil and causing Botryosphaeria dieback of grapevine were chemically identified. As ascertained by LC/MS, L. brasiliense, L. crassispora, L. jatrophicola, and L. pseudotheobromae produced jasmonic acid, and L. brasiliense synthesized, besides jasmonic acid, also (3R,4S)4-hydroxymellein. L. euphorbicola and L. hormozganensis produced some low molecular weight lipophilic toxins. Specifically, $L$. euphorbicola produced (-)-mellein, $(3 R, 4 R)-(-)$ - and $(3 R, 4 S)-(-)-4$-hydroxymellein, and tyrosol, and L. hormozganensis synthesized tyrosol and $p$-hydroxybenzoic acid. This is the first report on the production of the above cited metabolites from $L$. euphorbicola and L. hormozganensis. The phytotoxic activity of the metabolites produced is also discussed and related to the symptoms these pathogens cause in the grapevine host plants.

KEYWORDS: grapevine trunk diseases, Lasiodiplodia spp., Vitis vinifera, Botryosphaeria dieback, phytotoxins, melleins, tyrosol, p-hydroxybenzoic acid

\section{INTRODUCTION}

Fungal species in the Botryosphaeriaceae family are cosmopolitan plant pathogens causing fruit rot, leaf spot, dieback, cankers, and root rot of various angiosperms and gymnosperms. ${ }^{1}$ Many species of various genera in this family are important pathogens of grapevine in all the main grape-growing areas worldwide, where they cause wood cankers, stunted growth, dieback, light-brown stripes under the bark, and sectorial necrosis in the wood. ${ }^{2}$ Some of these Botryosphaeriaceae species are also reported to cause typical foliar symptoms in grapevine, ${ }^{3}$ and, since these species colonize only the wood, there is an increasing interest in the toxic compounds that they produce during the pathogenic process, and the role that these compounds may have in that process. In the genus Lasiodiplodia, 11 species, including L. brasiliense, L. crassispora, L. egyptiacae, L. euphorbicola, L. jatrophicola, L. hormozganensis, L. missouriana, L. parva, L. pseudotheobromae, L. theobromae, and L. viticola, have so far been reported as pathogenic on grapevine. $^{2,4-7}$ Of these, L. theobromae is one of the most widespread and aggressive, occurring mostly in the tropical and subtropical regions of the Americas and Australia, ${ }^{2,8}$ but also in the warmer areas of Europe and in the Mediterranean. ${ }^{9-11}$

Lasiodiplodia species were also investigated for their production of phytotoxic metabolites. A number of substances (jasmonic acid, mellein, lasiodiplodin, theobroxide, butyrolactones, botryospaeran, botryorodines, and lasiodiplodan among others) are produced in vitro by various isolates of $L$. theobromae and other Lasiodiplodia spp. in hosts other than grapevine, and these substances have been tested for their toxic activity. $^{12-22}$ L. mediterranea, recently isolated from grapevine and closely related to L. pseudotheobromae, ${ }^{23}$ produces in vitro three jasmonic acid esters, named lasiojasmonates $\mathrm{A}-\mathrm{C}$, and 16-O-acetylbotryosphaerilactones $\mathrm{A}$ and $\mathrm{C},(1 R, 2 R)$-jasmonic acid, its methyl ester, botryosphaerilactone A, (3S,4R,5R)-4hydroxymethyl-3,5-dimethyldihydro-2-furanone, and $(3 R, 4 S)$ botryodiplodin. ${ }^{24}$ Two different strains of L. pseudotheobromae, isolated from hosts other than grapevine, i.e., decaying fruit and root crops during storage, synthesize four palmarumycins, of which two are reported to have a cytotoxic effect on human promyelocytic leukemia cells, ${ }^{25}$ and six sulfureous diketopiperazines, designated as lasiodiplines $\mathrm{A}-\mathrm{F}$, with lasiodipline $\mathrm{E}$ having a strong antibacterial effect. ${ }^{26}$ None of the secondary metabolites produced by L. pseudotheobromae strains have been detected in the strains isolated from declining grapevines.

In a recent study on grapevines growing in Brazil and showing Botryosphaeria dieback symptoms, L. brasiliense, L. euphorbicola, L. hormozganensis, and L. jatrophicola were isolated, together with other Lasiodiplodia species previously reported on grapevine. ${ }^{7}$

The present study reports on the identification of low molecular weight (LMW) phytotoxins produced by six strains and in particular by L. euphorbicola and L. hormozganensis.

Received: November 2, 2016

Revised: January 17, 2017

Accepted: January 21, 2017

Published: January 22, 2017 


\section{MATERIALS AND METHODS}

General Experimental Procedure. Optical rotations were measured in $\mathrm{CHCl}_{3}$ on a Jasco P-1010 digital polarimeter (Tokyo, Japan). IR spectra were recorded as a deposit glass film on a Thermo Electron Corporation Nicolet 5700 FT-IR spectrometer (Madison, WI, USA), and UV spectra were measured in $\mathrm{MeCN}$ on a Jasco V-530 spectrophotometer; ${ }^{1} \mathrm{H}$ NMR spectra were recorded at 400 or 500 $\mathrm{MHz}$ in $\mathrm{CDCl}_{3}$ on Bruker (Karlsruhe, Germany) and Varian (Palo Alto, CA, USA) instruments. The same solvent was also used as an internal standard. ESI MS and LC/MS analyses were performed using the LC/MS TOF system (AGILENT 6230B, HPLC 1260 Infinity, Milan, Italy). The HPLC separations were performed with a Phenomenex LUNA (C18(2) $5 \mu \mathrm{m} 150 \times 4.6 \mathrm{~mm})$. Analytical and preparative TLCs were carried out on silica gel (Kieselgel $60, \mathrm{~F}_{254}, 0.25$ and $0.5 \mathrm{~mm}$ respectively) and on reverse phase (Kieselgel $60 \mathrm{RP}-18$, $\mathrm{F}_{254}, 0.20 \mathrm{~mm}$ ) plates (Merck, Darmstadt, Germany). The spots were visualized by exposure to UV radiation, or by spraying first with $10 \%$ $\mathrm{H}_{2} \mathrm{SO}_{4}$ in $\mathrm{MeOH}$, and then with $5 \%$ phosphomolybdic acid in EtOH, followed by heating at $110{ }^{\circ} \mathrm{C}$ for $10 \mathrm{~min}$. Column chromatography was performed using silica gel (Kieselgel 60, 0.063-0.200 mm) (Merck). Standard samples of racemic jasmonic acid and 4hydroxybenzoic acid and tyrosol were procured from Sigma-Aldrich (Saint Louis, MO, USA). Standard samples of scytalone and isosclerone and cis- $(3 R, 4 R)$ - and trans- $(3 R, 4 S)-(-)-4$-hydroxymelleins were isolated, repectively, from Phaeoacremonium minimum (syn. $P$. aleophilum) and Diplodia africana as reported in earlier works. ${ }^{27-29}$

Fungal Strains and Culture Conditions. The Lasiodiplodia strains used in this study were obtained from the collection of Universidade Federal Rural de Pernambuco, Recife, Brazil, and were $L$. crassispora CMM0390, L. euphorbicola CMM0181, L. hormozganensis CMM0126, L. jatrophicola CMM0840, L. pseudotheobromae CMM0204, and L. brasiliense CMM0418. All the strains were grown in stationary culture in $0.5 \mathrm{~L}$ Roux flasks, each containing $100 \mathrm{~mL}$ of modified Difco Czapek Dox medium (Benton, MD, USA) with 0.5\% yeast and $0.5 \%$ malt extract (both from Difco), for 21 days at $25^{\circ} \mathrm{C}$ in the dark. To obtain a greater amount of culture filtrate, L. euphorbicola CMM0181 and L. hormozganensis CMM0126 were also grown in six 2 L Roux flasks, each containing $600 \mathrm{~mL}$ of culture medium to reach a total volume of $3.6 \mathrm{~L}$ of liquid culture. Mycelium plugs from one-weekold colonies grown on potato dextrose agar were used to seed liquid cultures of Lasiodiplodia spp. At harvest, the mycelial mats were removed and the liquid cultures filtered through filter paper folded double and lyophilized prior to the extraction procedure.

Phytotoxic Activity Assay. The phytotoxic activity of the crude extract and chromatographic fractions were assayed on nonhost lemon fruits, as reported in a previous work. ${ }^{30}$ Briefly, the samples were dissolved in DMSO and diluted in distilled water to a final concentration of $1 \mathrm{mg} / \mathrm{mL}$ and $4 \%$ of DMSO. The peel of the lemon fruits was disinfected with sodium hypochlorite $(50 \mu \mathrm{g} / \mathrm{mL})$ and subsequently rinsed three times with sterile distilled water. A 10 $\mu \mathrm{L}$ drop of the test solution was placed on lemon peel, and the peel underneath the solution was punctured three times with the needle of a sterile syringe. The infiltrations were carried out in spring, at room temperature $\left(16-22{ }^{\circ} \mathrm{C}\right)$, and were examined after $72 \mathrm{~h}$. Ophiobolin and $5 \%$ DMSO in Milli-Q water were used as positive and negative controls, respectively.

LC/MS Analysis of the Culture Filtrates of Lasiodioplodia spp. Strains. The lyophilized residue of $100 \mathrm{~mL}$ of the culture filtrates of the Lasiodiplodia strains was dissolved in $10 \mathrm{~mL}$ of Milli-Q water; and five volumes of cold ethanol were added under stirring at $10{ }^{\circ} \mathrm{C}$. The suspensions were centrifuged at $7000 \mathrm{rpm}$ at the same temperature. The ethanolic phases were recovered and the precipitates resuspended and again precipitated as above. The polysaccharide content of the precipitates was measured following a recently described procedure. ${ }^{31}$ The standards of jasmonic acid (6), cis$(3 R, 4 R)$ - and trans-(3R,4S)-(-)-4-hydroxymelleins (2 and 3), scytalone, and isosclerone were compared by TLC analysis with the residues obtained from both ethanolic phases. The samples containing jasmonic acid were also analyzed by LC/MS. The LC/MS analyses were performed using the Agilent LC/MS TOF system. Samples were injected using a $20 \mu \mathrm{L}$ loop, eluted in isocratic conditions with $\mathrm{CH}_{3} \mathrm{CN} / \mathrm{H}_{2} \mathrm{O} 0.1 \%$ TFA (50:50) at a flow rate of $1 \mathrm{~mL} / \mathrm{min}$, and UV monitored for $10 \mathrm{~min}$. The metabolites were identified according to their retention time $\left(t_{\mathrm{R}}\right)$ and by ESI MS.

Extraction of LMW Phytotoxic Metabolites from $L$. euphorbicola CMM0181 and L. hormozganensis CMM0126. The lyophilized residues of the culture filtrates of L. euphorbicola CMM0181 (3.5 L) and L. hormozganensis CMM0126 (3.7 L) were dissolved in 400 and $300 \mathrm{~mL}$ of water, respectively. Three aliquots of $20 \mathrm{~mL}$ were taken from each culture filtrate: in the first aliquot the $\mathrm{pH}$ was acidified to $\mathrm{pH} 2$ with $1 \mathrm{M}$ formic acid, in the second the $\mathrm{pH}$ was alkalized to $\mathrm{pH} 9$ with $1 \mathrm{M} \mathrm{NH}_{4} \mathrm{OH}$, and in the third the $\mathrm{pH}$ of the culture filtrates $(\mathrm{pH} \mathrm{6})$ was kept unchanged. The organic phase was extracted with EtOAc $(3 \times 60 \mathrm{~mL})$. The organic extracts were then combined, dried $\left(\mathrm{Na}_{2} \mathrm{SO}_{4}\right)$, filtered, and evaporated under low pressure. The organic extracts were tested for toxicity on the lemon fruits by a preliminary procedure as described above.

Purification of LMW Phytotoxins from the Organic Extracts of L. euphorbicola CMM0181 and L. hormozganensis CMM0126. The residual aliquot of $340 \mathrm{~mL}$ of culture filtrate of $L$. euphorbicola was extracted at $\mathrm{pH} 6$ with EtOAc $(3 \times 300 \mathrm{~mL})$. The organic extracts were combined, dried $\left(\mathrm{Na}_{2} \mathrm{SO}_{4}\right)$, and evaporated under low pressure. The residue $(305 \mathrm{mg}$ ) was purified by silica gel column chromatography using $\mathrm{CHCl}_{3}-i-\mathrm{PrOH}(95: 5, \mathrm{v} / \mathrm{v})$. After TLC, the fractions were collected in seven separate groups, each group being tested for its phytotoxicity on lemon fruits. The residue of fraction one was purified by preparative TLC on silica gel using $\mathrm{CHCl}_{3}$ as an eluent; this yielded a white solid, which was identified as $(-)$-mellein $(1,9.4 \mathrm{mg})$. The residue of fraction two was purified by TLC on reverse phase, eluent $\mathrm{EtOH}-\mathrm{H}_{2} \mathrm{O}(1: 1, \mathrm{v} / \mathrm{v})$, yielding two amorphous solids, identified as $(3 R, 4 R)-$ and $(3 R, 4 S)-(-)-4-$ hydroxymelleins ( 2 and 3,1.2 and $1.9 \mathrm{mg}$ ). The residue of fraction four was purified on preparative TLC on silica gel, using $\mathrm{CHCl}_{3}-i$ $\mathrm{PrOH}(9: 1, \mathrm{v} / \mathrm{v})$ as an eluent; this yielded a white solid substance identified as tyrosol $(4,2.4 \mathrm{mg})$. The organic extract obtained from the residual culture filtrates $(240 \mathrm{~mL})$ of L. hormozganensis was extracted at $\mathrm{pH} 6$ with EtOAc $(3 \times 250 \mathrm{~mL})$. The organic extracts were combined, dried $\left(\mathrm{Na}_{2} \mathrm{SO}_{4}\right)$, and evaporated under low pressure. The residue $(325 \mathrm{mg}$ ) was purified by silica gel column chromatography, using $\mathrm{CHCl}_{3}-i-\mathrm{PrOH}(97: 3, \mathrm{v} / \mathrm{v})$ as an eluent, and yielded ten different fraction groups. Residue fraction six $(14 \mathrm{mg})$ was purified by preparative TLC, eluent $n$-hexane-acetone $(1: 1, \mathrm{v} / \mathrm{v})$, and yielded a white solid identified as tyrosol $(4,2.5 \mathrm{mg})$. Lastly, the residue of fraction eight $(18 \mathrm{mg})$ was purified by preparative TLC eluted with $n$ hexane- $\mathrm{Me}_{2} \mathrm{CO}(1: 1, \mathrm{v} / \mathrm{v})$, yielding an amorphous solid identified as p-hydroxybenzoic acid $(5,1.9 \mathrm{mg})$.

Identification of Compounds 1-6. Compounds 1-6 were identified by comparing their spectroscopic data $\left({ }^{1} \mathrm{H}\right.$ NMR and ESI/ MS) with those already reported in the literature. ${ }^{14,24,32-40}$

(-)-Mellein (1). ${ }^{1} \mathrm{H}$ NMR (500 MHz, in $\mathrm{CDCl}_{3}$ ), $\delta: 11.03$ (s, HO8), $7.41(\mathrm{t}, J=8.4 \mathrm{~Hz}, \mathrm{H}-6), 6.89(\mathrm{~d}, J=8.4 \mathrm{~Hz}, \mathrm{H}-7), 6.69(\mathrm{~d}, J=8.4$ $\mathrm{Hz}, \mathrm{H}-5), 4.74(\mathrm{tq}, J=6.9$ and $6.3 \mathrm{~Hz}, \mathrm{H}-3), 2.93\left(\mathrm{~d}, J=6.9 \mathrm{~Hz}, \mathrm{H}_{2}-4\right)$, $1.53(\mathrm{~d}, J=6.3 \mathrm{~Hz}, \mathrm{Me}-3)$. ESI/MS (+), $m / z: 179[\mathrm{M}+\mathrm{H}]^{+}$. These data are in agreement with the data previously reported. ${ }^{32,34-37}$

(3R,4R)-(-)-4-Hydroxymellein (2). ${ }^{1} \mathrm{H} \mathrm{NMR}\left(400 \mathrm{MHz}\right.$, in $\left.\mathrm{CDCl}_{3}\right)$, $\delta: 10.99(\mathrm{~s}, \mathrm{HO}-8), 7.55(\mathrm{t}, J=7.6 \mathrm{~Hz}, \mathrm{H}-6), 7.03(\mathrm{~d}, J=7.6 \mathrm{~Hz}, \mathrm{H}-7)$, 7.00 (d, J = 7.6 Hz, H-5), 4.60 (m, H-3 and H-4), 1.53 (d, $J=6.1 \mathrm{~Hz}$, Me-C3). ESI/MS $(+), m / z: 195[\mathrm{M}+\mathrm{H}]^{+}$. These data are in agreement with the data previously reported. ${ }^{32,34-37}$

(3R,4S)-(-)-4-Hydroxymellein (3). ${ }^{1} \mathrm{H}$ NMR $\left(400 \mathrm{MHz}\right.$, in $\left.\mathrm{CDCl}_{3}\right)$ and ESI/MS (+) data are very similar to those of 2 . These data are also in agreement with the data previously reported. ${ }^{32-37}$

Tyrosol (4). ${ }^{1} \mathrm{H}$ NMR (500 MHz, in $\left.\mathrm{CDCl}_{3}\right), \delta: 7.20$ (d, $J=8.0 \mathrm{~Hz}$, (H-2 and H-6), 6.80 (d, J = 8.0 Hz, H-3 and H-5), $4.90(\mathrm{~s}, \mathrm{OH}), 3.80$ $\left(\mathrm{t}, J=6.4 \mathrm{~Hz}, \mathrm{H}_{2}-8\right), 2.80\left(\mathrm{t}, J=6.4 \mathrm{~Hz}, \mathrm{H}_{2}-7\right)$. ESI/MS (+), $m / z: 295$ $[2 \mathrm{M}+\mathrm{Na}]^{+}, 159[\mathrm{M}+\mathrm{Na}]^{+}$. These data are in agreement with those previously reported. 37,38

p-Hydroxybenzoic Acid (5). ${ }^{1} \mathrm{H}$ NMR $\left(500 \mathrm{MHz}\right.$, in $\left.\mathrm{CDCl}_{3}\right), \delta$ : $7.91(\mathrm{~d}, J=8.6 \mathrm{~Hz}, \mathrm{H}-2$ and $\mathrm{H}-6), 7.04(\mathrm{~d}, J=8.6 \mathrm{~Hz}, \mathrm{H}-3$ and $\mathrm{H}-5)$. 
Table 1. LMW Lipophilic Compounds Identified in the Organic Extract of Culture Filtrates of Lasiodiplodia spp. Isolated from Grapevine in Brazil ${ }^{a}$

\begin{tabular}{|c|c|c|c|c|c|c|c|}
\hline \multirow[b]{2}{*}{ strain } & \multirow[b]{2}{*}{ species } & \multicolumn{5}{|c|}{ metabolites isolated from culture filtrates } & \multirow[b]{2}{*}{$\begin{array}{c}\text { jasmonic acid } \\
(6)\end{array}$} \\
\hline & & $\begin{array}{c}(R)- \\
(-) \text {-mellein }(1)\end{array}$ & $\begin{array}{c}(3 R, 4 R-)-(-)-4- \\
\text { hydroxymellein }(2)\end{array}$ & $\begin{array}{c}(3 R, 4 S)-(-)-4- \\
\text { hydroxymellein (3) }\end{array}$ & $\begin{array}{l}\text { tyrosol } \\
\text { (4) }\end{array}$ & $\begin{array}{c}\text { p-hydroxybenzoic } \\
\text { acid (5) }\end{array}$ & \\
\hline CMM0418 & L. brasiliense & & & $x$ & & & $x$ \\
\hline CMM0390 & L. crassispora & & & & & & $x$ \\
\hline CMM0181 & L. euphorbicola & $\times$ & $\times$ & $\times$ & $\times$ & & \\
\hline CMM0126 & L.hormozganensis & & & & $x$ & $\times$ & \\
\hline CMM0840 & L. jatrophicola & & & & & & $x$ \\
\hline СMM0204 & $\begin{array}{l}\text { L. pseudotheo- } \\
\text { bromae }\end{array}$ & & & & & & $x$ \\
\hline
\end{tabular}

ESI/MS, $m / z: 139[\mathrm{M}+\mathrm{H}]^{+}$. These data are in agreement with the data previously reported. ${ }^{40}$

Jasmonic Acid (6). ${ }^{1} \mathrm{H}$ NMR $\left(400 \mathrm{MHz}\right.$, in $\left.\mathrm{CDCl}_{3}\right), \delta: 5.46(\mathrm{~m}, \mathrm{H}-$ 10), 5.29 (m, H-9), 2.70-1.40 (12 H, m), $0.98(\mathrm{t}, J=7.7 \mathrm{~Hz}, \mathrm{Me}-12)$. ESI/MS, $m / z: 211[\mathrm{M}+\mathrm{H}]^{+}$. These data are in agreement with the data previously reported. ${ }^{14,24}$

\section{RESULTS}

Analysis of the ethanolic supernatants obtained by EPS precipitation indicated that only $L$. brasiliense, L. crassispora, L. jatrophicola, and L. pseudotheobromae produced jasmonic acid (JA, 6), as revealed by TLC and LC/MS (Table 1). JA present in all organic phases showed by TLC and HPLC the same $R_{f}$ of 0.29 and $t_{\mathrm{R}}$ of $4.30 \mathrm{~min}$ also when coinjected with a standard commercial sample of racemic jasmonic acid. Moreover, with ESI/MS analysis the corresponding peak showed the expected pseudomolecular ion $[\mathrm{M}+\mathrm{H}]^{+}$at $m / z 211$. Lastly, JA purified from the ethanolic phase of $L$. brasiliense had spectroscopic properties $\left({ }^{1} \mathrm{H}\right.$ NMR and ESI/MS) identical to those reported for jasmonic acid (6). ${ }^{14,24}$ In L. brasiliense one more compound was identified that had the same $R_{f}$ of 0.37 and $t_{\mathrm{R}}$ of $2.76 \mathrm{~min}$ of $(3 R, 4 S)-(-)-4$-hydroxymellein (3) (Table 1) when it was coinjected with the corresponding standard, while with ESI/MS analysis the corresponding peak showed the expected pseudomolecular ion $[\mathrm{M}+\mathrm{H}]^{+}$at $\mathrm{m} / z$ 195. The compound had the same physical and spectroscopic $\left({ }^{1} \mathrm{H}\right.$ NMR and ESI/ MS) properties as those previously reported for $(-)-(3 R, 4 S)$ (-)-4-hydroxymellein (3). ${ }^{32-34}$ Thus, the metabolites 1, 2, 4, and $\mathbf{5}$ were not produced from these Lasiodiplodia strains as reported in Table 1 .

An aliquot $(20 \mathrm{~mL})$ of the culture filtrates of L. euphorbicola CMM0181 and L. hormozganensis CMM0126 was extracted at unmodified $\mathrm{pH}(\mathrm{pH}$ 6), and in acidic $(\mathrm{pH} 2)$ and basic $(\mathrm{pH} 9)$ conditions, and the corresponding organic extracts were assayed on lemon fruits. Both of these were most toxic on lemon when the extraction was carried out at unchanged culture filtrate $\mathrm{pH}$. This also produced the highest yield of the metabolites extracted. The organic extracts of the residual culture filtrates of L. euphorbicola $(340 \mathrm{~mL}, 305 \mathrm{mg})$ and $L$. hormozganensis $(240 \mathrm{~mL}, 325 \mathrm{mg}$ ) were purified by combined column and TLC on normal and reverse phases. Only fractions 1,2 , and 4 and fractions 6 and 8 , obtained by purification of the above from $L$. euphorbicola and L. hormozganensis extracts, respectively, were toxic on lemon. Purification of the extracts allowed four pure metabolites to be isolated from $L$. euphorbicola, and two from L. hormozganensis.

The four metabolites isolated from $L$. euphorbicola were identified as (R)-(-)-mellein, $(3 R, 4 R)-(-)$ - and $(3 R, 4 S)$ (-)-4-hydroxymellein, and tyrosol (1-4, Figure 1) by<smiles>CC1Cc2cccc(O)c2C(=O)O1</smiles>

1, (-)-Mellein<smiles>CC1OC(=O)c2c(O)cccc2C1O</smiles>

2, $(3 R, 4 R)-4-$ Hydroxymellein<smiles>O=C(O)c1ccc(O)cc1</smiles>

5, p-Hydroxybenzoic acid

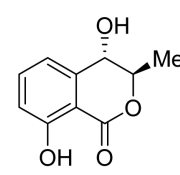

3, $(3 R, 4 S)-4-$ Hydroxymellein

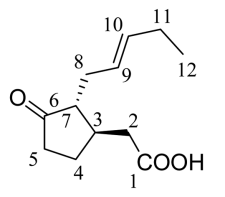

6, Jasmonic acid
4, Tyrosol

Figure 1. Structure of $(-)$-mellein, $(3 R, 4 R)$ - and $(3 R, 4 S)-4$ hydroxymellein, and tyrosol (1-4) isolated from Lasiodiplodia euphorbicola and $p$-hydroxybenzoic acid (5) isolated from $L$. hormozganensis together with tyrosol. Structure of jasmonic acid (6) produced by the other Lasioplodia strains.

comparing their physical $\left([\alpha]_{\mathrm{D}}^{25}\right)$ and spectroscopic $\left({ }^{1} \mathrm{H}\right.$ NMR and ESI/MS) properties with those reported in earlier studies. $^{12,32-39}$ The two metabolites isolated from $L$. hormozganensis were identified as tyrosol and 4-hydroxybenzoic acid (5, Figure 1) by comparing their spectroscopic properties $\left({ }^{1} \mathrm{H}\right.$ NMR and ESI-MS) with those reported in the literature for 4 (as above) and for 5, ${ }^{40}$ and also by comparison with a commercial standard.

None of the Lasiodiplodia strains tested produced scytalone or isosclerone.

\section{DISCUSSION}

In this study we reported on the production of secondary metabolites by various species of Lasiodiplodia associated with grapevine trunk diseases in Brazil. Four (L. brasiliense, L. crassispora, L. jatrophicola, and L. pseudotheobromae) out of six species examined synthesized the well-known plant hormone jasmonic acid (6) usually produced in response to wounding caused by insects and necrothrophic microbes. ${ }^{41,42}$ Jasmonic acid (6) was also isolated from $L$. theobromae ${ }^{43}$ and recently also as the main phytotoxin produced by L. mediterranea, together with its methyl ester its three new furanonenyl esters named lasiojasmonates $\mathrm{A}-\mathrm{C} .{ }^{24}$ In the same work these authors reported that jasmonic acid (6) also caused vein necrosis on detached grapevine leaves. Only $L$. brasiliense and $L$. euphorbicola produced $(3 R, 4 S)-(-)-4$-hydroxymellein (3). L. euphorbicola also synthesized $(R)-(-)$-mellein $(1)$ and $(3 R, 4 R$ )-(-)-4-hydroxymellein (2), which had previously been isolated as toxic metabolites produced by Botryosphaeriaceae species causing grapevine decline, namely, Neofusiccoccum parvum, $^{36,37}$ Diplodia seriata, ${ }^{42,43}$ and Sphaeropsis sapinea, the 


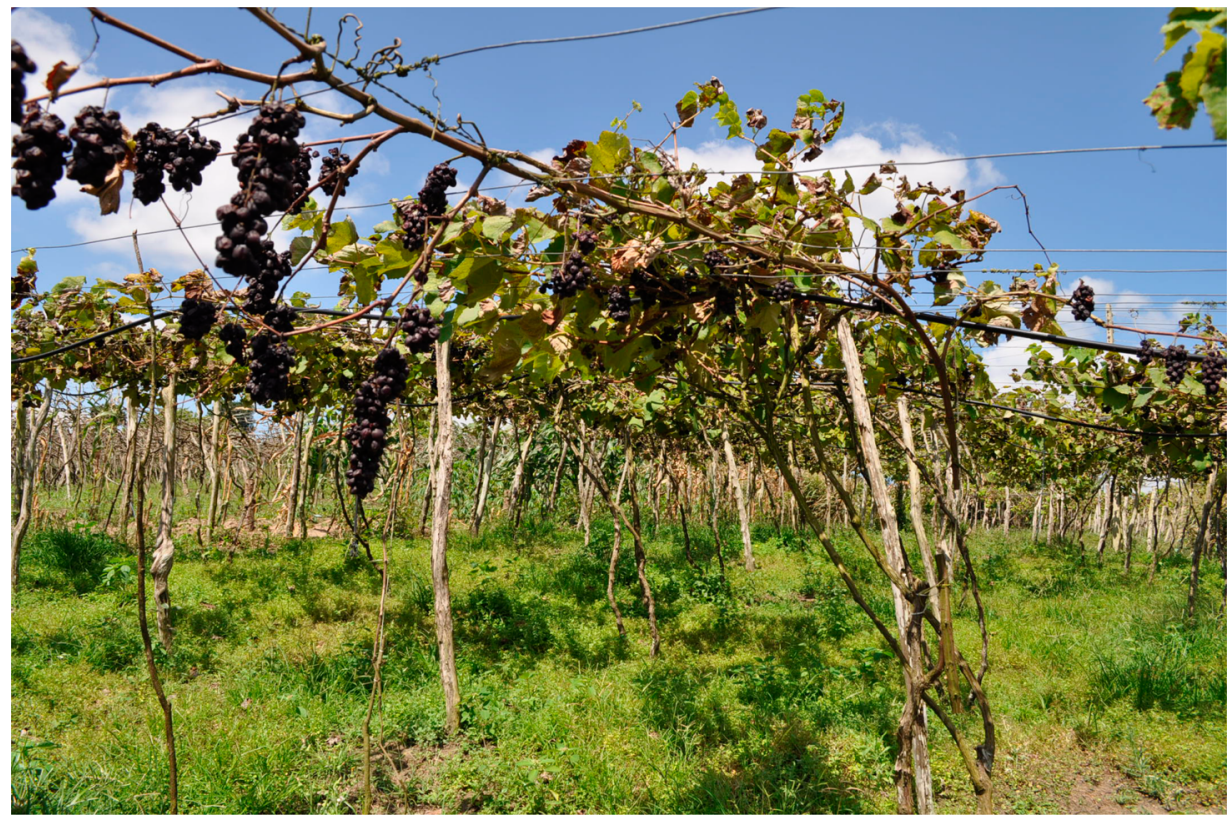

Figure 2. Decline and cluster wilting in a vine (cultivar Isabel) heavily affected with wood cankers caused by Lasiodiplodia species in the Valley of Siriji in Pernambuco, Brazil.

causal agent of pine decline. ${ }^{34}$ The phytotoxic effect of $(3 R, 4 R)-(-)$ and $(3 R, 4 S)-(-)-4$-hydroxymellein (2 and 3$)$ has previously been assayed on tomato cuttings, ${ }^{37}$ on which it produced only a slight wilting, and on grapevine leaves, ${ }^{35,36}$ where it caused necrosis.

Melleins are metabolites produced by many fungi in various genera such as Aspergillus, Cryptosporiopsis, Hypoxylon, Microsphaeropsis, Pezicula, Phoma, Plectophomella, Septoria, and Xylaria, which showed different phytotoxic, zootoxic, and moderate antifungal effects. ${ }^{37}(-)$-Mellein (1) was toxic on grapevine leaves and grapevine calli. ${ }^{37,36,44,45}$ Moreover, on grapevines affected with Botryosphaeria dieback and grapevine leaf stripe disease, (-)-mellein (1) was detected in symptomatic and asymptomatic wood samples and in green shoots. $^{38}$ Since (-)-mellein (1) is produced by many Botryosphaeriaceae species, its role in pathogenesis was investigated by examining the extent to which it caused the expression of defense-related genes in grapevine calli. A significant expression of defense-related genes was recorded only after 6 days, and at a dose of $500 \mu \mathrm{g} \mathrm{mL}^{-1}$, which is 100 times greater than the amount of $(-)$-mellein $(\mathbf{1})$ produced in vitro by $N$. parvum, calling into question the involvement of $(-)$-mellein (1) in the Botryosphaeria dieback and leaf stripe disease. $^{46}$

Tyrosol (4), produced by L. euphorbicola and L. hormozganensis, was also isolated from D. seriata, ${ }^{44,45} \mathrm{Neo}$ fusicoccum australe, associated with grapevine cordon and branch dieback, ${ }^{47}$ and N. parvum. ${ }^{37}$ Tyrosol (4) not only is toxic to tomato cuttings ${ }^{37}$ but also is a quorum sensing molecule in C. albicans, controlling growth, morphogenesis, and biofilm formation. ${ }^{48}$

4-Hydroxybenzoic acid (5) has been found in the root exudate of grapevine and other plants ${ }^{49-51}$ and has more recently been reported as one of the metabolites produced by Diaporthe gulyae, a fungal species that has been proposed as a mycoherbicide to control the annual weed Carthamus lanatus. ${ }^{52}$ 4-Hydroxybenzoic acid (5) is toxic to lettuce seedlings ${ }^{51}$ and inhibits radish and grain sorghum germination and growth, ${ }^{50}$ the growth of Brassica kaber roots and hypocotyls, ${ }^{53}$ germination of lettuce seeds, and the growth of various seaweeds. ${ }^{54}$ It also has a significant autotoxicity effect on tissue culture plantlets, and potted cuttings of grapevine. ${ }^{49}$ It is also produced by oil palm plants, in which at high concentrations it inhibits in vitro growth of the fungal pathogen Ganoderma boninense. $^{55}$

It is still difficult to link the occurrence of these metabolites in the culture filtrate of Lasiodiplodia strains from grapevine to the disease symptoms seen in those vines in the field. The disease reported in general terms as Botryosphaeria dieback ${ }^{2}$ also includes Lasiodiplodia species as its causal agents. V-shaped cankers are the symptoms most definitely associated with these Lasiodiplodia species (mainly $L$. theobromae, but also $L$. missouriana, L. crassispora, and L. viticola). ${ }^{24}$ There are occasional reports of other symptoms: dark streaks, root necrosis, and fruit rot. ${ }^{2}$ L. theobromae was reported as possibly causing foliar chlorosis, in a vine where colonization was particularly heavy. ${ }^{10}$ But all the Lasiodiplodia species isolated from grapevine in Brazil reported here were associated with Vshape necrosis that caused a general decline in the vines, and death of the cordon or main branches, but with no specific or characteristic leaf symptoms (Figures 2 and 3). Nevertheless it can be hypothesized that when phytotoxic metabolites are produced, they are translocated to the vine leaves by the plant sap, and cause damage to different components of the cell, affecting the physiology and normal growth of the vine, even if no symptoms become visible other than a decline. This is what happens with Eutypa lata. ${ }^{56}$ Further study is therefore required to ascertain whether the phytotoxins here isolated from the Brazilian Lasiodiplodia strains have a role in the Botryosphaeria dieback of grapevine, relating the production of these phytotoxins in vivo to their activity in planta.

However, the secondary bioactive metabolites produced by phytopathogenic fungi can contribute, together with the traditional taxonomic investigations, to better characterize the biodiversity and systematic of species belonging to the same fungal genus. Our findings extend the knowledge on the 


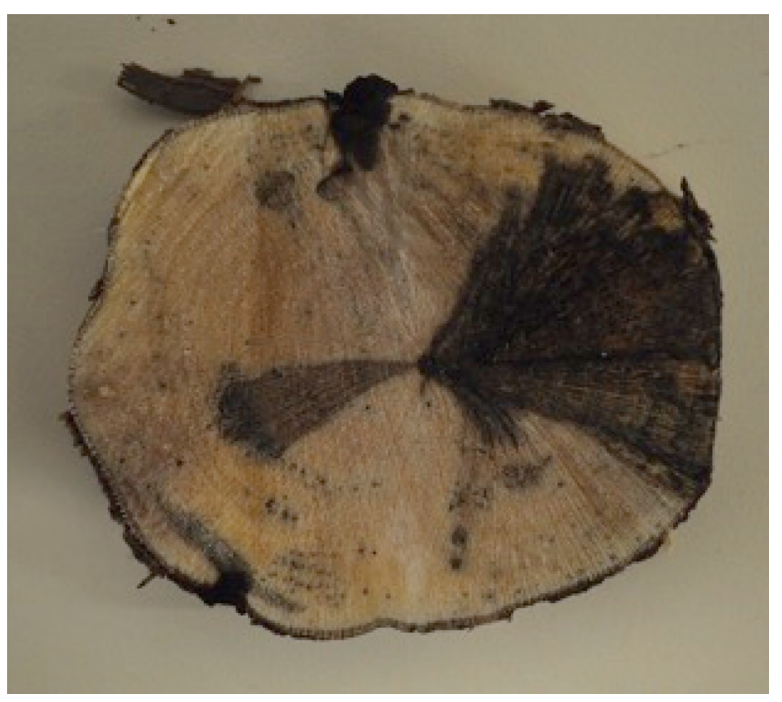

Figure 3. Trunk portions of infected vines and V-shaped necroses caused by Lasiodiplodia.

secondary metabolite pattern of Lasiosiplodia spp., which could represent a fingerprint of the studied species. For example, jasmonic acid (6) was biosythesized by four (L. brasiliense, $L$. crassispora, $L$. jatrophicola, and $L$. pseudotheobromae) of the Lasiodiplodia species studied in the present work, as well as by L. mediterannea. ${ }^{24}$ Also (-)-mellein (1) and 4-hydroxymelleins (2 and 3) were produced from other species such as $L$. brasiliense and $L$. euphorbicola. On the other hand, specific metabolites occur in a single species only; for example, lasiodiplodins synthesized from $L$. theobromae; ${ }^{57}$ jasmonic acid (6), its methyl and 4-hydroxymethyl-3,5-dimethyldihydro-2-furanone and 4-(4-hydroxy-3,5-dimethyltetrahydro-furan2-yloxymethyl)-3,5-dimethyl dihydro-2-furanone esters and 16$\mathrm{O}$-acetylbotryosphaerilactones $\mathrm{A}$ and $\mathrm{C}$ were produced only from $L$. mediterranea ${ }^{24}$ and $p$-hydroxybenzoic acid (5) from $L$. hormozganensis as reported in this work.

\section{AUTHOR INFORMATION}

\section{Corresponding Author}

*Tel: +39 0552755861. E-mail: laura.mugnai@unifi.it.

\section{ORCID ${ }^{\oplus}$}

Laura Mugnai: 0000-0002-2508-9764

Antonio Evidente: 0000-0001-9110-1656

Notes

The authors declare no competing financial interest.

\section{ACKNOWLEDGMENTS}

This work was carried out in the framework of COST action 1303: "Sustainable control of grapevine trunk diseases". Prof. Antonio Evidente is associated with the Istituto di Chimica Biomolecolare del CNR, Pozzuoli, Italy.

\section{REFERENCES}

(1) Phillips, A. J. L.; Alves, A.; Abdollahzadeh, J.; Slippers, B.; Wingfield, M. J.; Groenewald, J. Z.; Crous, P. W. The Botryosphaeriaceae: genera and species known from culture. Stud. Mycol. 2013, 76, 51-167.

(2) Úrbez-Torres, J. R. The status of Botryosphaeriaceae species infecting grapevine. Phytopathol. Mediterr. 2011, 50, S5-S45.

(3) Reis, P.; Magnin-Robert, M.; Nascimento, T.; Spagnolo, A.; Abou-Mansour, E.; Fioretti, C.; Fontaine, F. Reproducing Botryos- phaeria dieback foliar symptoms in a simple model system. Plant Dis. 2016, 100, 1071-1079.

(4) Correia, K. C.; Câmara, M. P. S.; Barbosa, M. A. G.; Sales, R., Jr.; Agustí-Brisach, C.; Gramaje, D.; Leon, M.; Garcia-Jimenez, J.; AbadCampos, P.; Armegol, J.; Michereff, S. J. Fungal trunk pathogens associated with table grape decline in Northeastern Brazil. Phytopathol. Mediterr. 2013, 52, 380-387.

(5) Pitt, W. M.; Huang, R.; Steel, C. C.; Savocchia, S. Pathogenicity and epidemiology of Botryosphaeriaceae species isolated from grapevines in Australia. Australas. Plant Pathol. 2013, 42, 573-82.

(6) Yan, J.-Y.; Xie, Y.; Zhang, W.; Wang, Y.; Liu, J.-K.; Hyde, K. D.; Seem, R. C.; Zhang, G.-Z.; Wang, Z.-Y.; Yao, S.-W.; Bai, X.-J.; Dissanayake, A. J.; Peng, Y.-L.; Li, X.-H. Species of Botryosphaeriaceae involved in grapevine dieback in China. Fungal Div. 2013, 61, 221-36.

(7) Correia, K. C.; Silva, M. A.; de Morais, M. A., Jr.; Armengol, J.; Phillips, A. J. L.; Câmara, M. P. S.; Michereff, S. J. Phylogeny, distribution and pathogenicity of Lasiodiplodia species associated with dieback of table grape in the main Brazilian exporting region. Plant Pathol. 2016, 65, 92-103.

(8) Alves, A.; Crous, P. W.; Correia, A.; Phillips, A. J. L. Morphological and molecular data reveal cryptic speciation in Lasiodiplodia theobromae. Fungal Div. 2008, 28, 1-13.

(9) El-Goorani, M. A.; El Meleigi, M. A. Dieback of grapevine by Botryodiplodia theobromae Pat. In Egypt. Phtopatol. Mediterr. 1972, 11, 210-211.

(10) Burrano, S.; Mondello, V.; Conigliaro, G.; Alfonzo, A.; Spagnolo, A.; Mugnai, L. Grapevine decline in Italy caused by Lasiodiplodia theobromae. Phytopathol. Mediterr. 2008, 47, 132-136.

(11) Aroca, A.; Raposo, R.; Gramaje, D.; Armengol, J.; Martos, S.; Luque, J. First report of Lasiodiplodia theobromae associated with decline of grapevine rootstock mother plants in Spain. Plant Dis. 2008, 92, 832-832.

(12) Aldridge, D. C.; Galt, S.; Giles, D.; Turner, W. B. Metabolites of Lasiodiplodia theobromae. J. Chem. Soc. C 1971, 1623-1627.

(13) Husain, A.; Ahmad, A.; Agrawal, K. P. (-)-Jasmonic acid, a phytotoxic substance from Botryodiplodia theobromae: characterization by NMR spectroscopic methods. J. Nat. Prod. 1993, 56, 2008-2011.

(14) Nakamori, K.; Matsuura, H.; Yoshihara, T.; Ichihara, A.; Koda, Y. Potato-microtuber inducing substances from Lasiodiplodia theobromae. Phytochemistry 1994, 35, 835-839.

(15) Matsuura, H.; Obara, N.; Chisaka, N.; Ichihara, A.; Yoshihara, T. Novel cyclohexene compound from Lasiodiplodia theobromae IFO 31059. Biosci., Biotechnol., Biochem. 1998, 62, 2460-2462.

(16) Yang, Q.; Asai, M.; Matsuura, H.; Yoshihara, T. Potato microtuber inducing hydroxylasiodiplodins from Lasiodiplodia theobromae. Phytochemistry 2000, 54, 489-494.

(17) He, G.; Matsuura, H.; Yoshihara, T. Isolation of an $\alpha$ methylene- $\gamma$-butyrolactone derivative, a toxin from the plant pathogen Lasiodiplodia theobromae. Phytochemistry 2004, 65, 2803-2807.

(18) Miranda, C. C. B. O.; Dekker, R. F. H.; Serpeloni, J. M.; Fonseca, E. A. I.; Cólus, I. M. S.; Barbosa, A. M. Anticlastogenic activity exhibited by botryosphaeran, a new exopolysaccharide produced by Botryosphaeria rhodina MAMB-05. Int. J. Biol. Macromol. 2008, 42, 172-177.

(19) Kitaoka, N.; Nabeta, K.; Matsuura, H. Isolation and structural elucidation of a new cyclohexenone compound from Lasiodiplodia theobromae. Biosci., Biotechnol., Biochem. 2009, 73, 1890-1892.

(20) Abdou, R.; Scherlach, K.; Dahse, H. M.; Sattler, I.; Hertweck, C. Botryorhodines $\mathrm{A}-\mathrm{D}$, antifungal and cytotoxic depsidones from Botryosphaeria rhodina, an endophyte of the medicinal plant Bidens pilosa. Phytochemistry 2010, 71, 110-116.

(21) Pandi, M.; Manikandan, R.; Muthumary, J. Anticancer activity of fungal taxol derived from Botryodiplodia theobromae Pat., an endophytic fungus, against 7,12-dimethyl benz $(\alpha)$ anthracene (DMBA)-induced mammary gland carcinogenesis in Sprague dawley rats. Biomed. Pharmacother. 2010, 64, 48-53.

(22) da Cunha, M. A. A.; Turmina, J. A.; Ivanov, R. C.; Barroso, R. R.; Marques, P. T.; Fonseca, E. A. I.; Fortes, Z. B.; Dekker, R. F. H.; Khaper, N.; Barbosa, A. M. Lasiodiplodan, an exocellular $(1 \rightarrow 6)-\beta$-D- 
glucan from Lasiodiplodia theobromae MMPI: production on glucose, fermentation kinetics, rheology and anti-proliferative activity. J. Ind. Microbiol. Biotechnol. 2012, 39, 1179-1188.

(23) Linaldeddu, B. T.; Deidda, A.; Scanu, B.; Franceschini, A.; Serra, S.; Berraf-Tebbal, A.; Bouiti, M. Z.; Ben Jamâa, M. L.; Phillips, A. J. L. Diversity of Botryosphaeriaceae species associated with grapevine and other woody hosts in Italy, Algeria and Tunisia, with descriptions of Lasiodiplodia exigua and Lasiodiplodia mediterranea sp. nov. Fungal Divers. 2015, 71, 201-214.

(24) Andolfi, A.; Maddau, L.; Cimmino, A.; Linaldeddu, B. T.; Basso, S.; Deidda, A.; Serra, S.; Evidente, A. Lasiojasmonates A-C, three jasmonic acid esters produced by Lasiodiplodia sp., a grapevine pathogen. Phytochemistry 2014, 103, 145-153.

(25) Lue, X.; Chen, G.; Li, Z.; Zhang, Y.; Wang, Z.; Rong, W.; Bai, J. Palmarumycins from the endophytic fungus Lasiodiplodia pseudotheobromae XSZ-3. Helv. Chim. Acta 2014, 97, 1289-1294.

(26) Wei, W.; Jiang, N.; Mei, Y. N.; Chu, Y. L.; Ge, H. M.; Song, Y. C.; Tan, R. X. An antibacterial metabolite from Lasiodiplodia pseudotheobromae F2. Phytochemistry 2014, 100, 103-109.

(27) Evidente, A.; Superchi, S.; Cimmino, A.; Mazzeo, G.; Mugnai, L.; Rubiales, D.; Andolfi, A.; Villegas-Fernández, A. M. Regiolone and isosclerone, two enantiomeric phytotoxic naphthalenone pentaketides: computational assignment of absolute configuration and its relationship with phytotoxic activity. Eur. J. Org. Chem. 2011, 2011, 55645570.

(28) Evidente, A.; Sparapano, L.; Andolfi, A.; Bruno, G. Two naphthalenone pentaketides from liquid cultures of Phaeoacremonium aleophilum, a fungus associated with esca of grapevine. Phytopathol. Mediterr. 2000, 39, 162-168.

(29) Evidente, A.; Masi, M.; Linaldeddu, B. T.; Franceschini, A.; Scanu, B.; Cimmino, A.; Andolfi, A.; Motta, A.; Maddau, L. Afritoxinones A and B, dihydrofuropyran-2-ones produced by Diplodia africana the causal agent of branch dieback on Juniperus phoenicea. Phytochemistry 2012, 77, 245-250.

(30) Andolfi, A.; Ferrante, P.; Petriccione, M.; Cimmino, A.; Evidente, A.; Scortichini, M. Production of phytotoxic metabolites by Pseudomonas syringae pv. actinidiae, the causal agent of bacterial canker of kiwifruit. J. Plant Pathol. 2014, 96, 169-176.

(31) Cimmino, A.; Cinelli, T.; Evidente, M.; Masi, M.; Mugnai, L.; Silva, M. A.; Michereff, S. J.; Surico, G.; Evidente, A. Phytotoxic fungal exopolysaccharides produced by fungi involved in grapevine trunk diseases. Nat. Prod. Comm. 2016, 11, 1481-1484.

(32) Cole, R. J.; Cox, R. H. Handbook of Toxic Fungal Metabolites; Academic Press: New York, NY, USA, 1981; Vol. 3, pp 623-624.

(33) Devys, M.; Barbier, M.; Bousquet, J. F.; Kollmann, A. Isolation of the new (-)-(3R,4S)-4 hydroxymellein from the fungus Septoria nodorum Berk. Z. Naturforsch., C 1992, 47, 779-881.

(34) Cabras, A.; Mannoni, M. A.; Serra, S.; Andolfi, A.; Fiore, M.; Evidente, A. Occurrence, isolation and biological activity of phytotoxic metabolites produced in vitro by Sphaeropsis sapinea, pathogenic fungus of Pinus radiata. Eur. J. Plant Pathol. 2006, 115, 187-193.

(35) Djoukeng, J. D.; Polli, S.; Larignon, P.; Abou-Mansour, E. Identification of phytotoxins from Botryosphaeria obtusa, a pathogen of black dead arm disease of grapevine. Eur. J. Plant Pathol. 2009, 124, 303-308.

(36) Abou-Mansour, E.; Débieux, J.; Ramirez-Suero, M.; BénardGellon, M.; Magnin-Robert, M.; Spagnolo, A.; Chong, J.; Farine, S.; Bertsch, C.; L’Haridon, F.; Serrano, M.; Fontaine, F.; Rego, C.; Larignon, P. Phytotoxic metabolites from Neofusicoccum parvum, a pathogen of Botryosphaeria dieback of grapevine. Phytochemistry 2015, 115, 207-215.

(37) Evidente, A.; Punzo, B.; Andolfi, A.; Cimmino, A.; Melck, D.; Luque, J. Lipophilic phytotoxins produced by Neofusicoccum parvum, a grapevine canker agent. Phytopathol. Mediterr. 2010, 49, 74-79.

(38) Kimura, Y.; Tamura, S. Isolation of $1-\beta$-phenyllactic acid and tyrosol as plant-growth regulators from Gloeosporium laeticolor. Agric. Biol. Chem. 1973, 37, 2925-2925.
(39) Capasso, R.; Cristinzio, G.; Evidente, A.; Scognamiglio, F. Isolation, spectroscopy and selective phytotoxic effects of polyphenols from vegetable waste waters. Phytochemistry 1992, 31, 4125-4128.

(40) Zhang, H.; Conte, M. M.; Huang, X. C.; Khalil, Z.; Capon, R. J. A search for BACE inhibitors reveals new biosynthetically related pyrrolidones, furanones and pyrroles from a southern Australian marine sponge, Ianthella sp. Org. Biomol. Chem. 2012, 10, 2656-2663.

(41) Thomma, B. P.; Eggermont, K.; Penninckx, I. A.; Mauch-Mani, B.; Vogelsang, R.; Cammue, B. P.; Broekaert, W. F. Separate jasmonate-dependent and salicylate-dependent defense-response pathways in Arabidopsis are essential for resistance to distinct microbial pathogens. Proc. Natl. Acad. Sci. U. S. A. 1998, 95, 15107-15111.

(42) van Wees, S. C.; Chang, H. S.; Zhu, T.; Glazebrook, J. Characterization of the early response of Arabidopsis to Alternaria brassicicola infection using expression profiling. Plant Physiol. 2003, $132,606-617$

(43) Tsukada, K.; Takahashi, K.; Nabeta, K. Biosynthesis of jasmonic acid in a plant pathogenic fungus, Lasiodiplodia theobromae. Phytochemistry 2010, 71, 2019-2023.

(44) Venkatasubbaiah, P.; Chilton, W. S. Phytotoxins of Botryosphaeria obtusa. J. Nat. Prod. 1990, 53, 1628-1630.

(45) Venkatasubbaiah, P.; Sutton, T. B.; Chilton, W. S. Effect of phytotoxins produced by Botryosphaeria obtusa, the cause of black rot of apple fruit and frogeye leaf spot. Phytopathology 1991, 81, 243-247.

(46) Ramirez-Suero, M.; Bénard-Gellon, M.; Chong, J.; Laloue, H.; Stempien, E.; Abou-Mansour, E.; Bertsch, C. Extracellular compounds produced by fungi associated with Botryosphaeria dieback induce differential defence gene expression patterns and necrosis in Vitis vinifera cv. Chardonnay cells. Protoplasma 2014, 251, 1417-1426.

(47) Andolfi, A.; Maddau, L.; Cimmino, A.; Linaldeddu, B. T.; Franceschini, A.; Serra, S.; Basso, S.; Melck, D.; Evidente, A. Cyclobotryoxide, a phytotoxic metabolite produced by the plurivorous pathogen Neofusicoccum australe. J. Nat. Prod. 2012, 75, 1785-1791.

(48) Albuquerque, P.; Casadevall, A. Quorum sensing in fungi-a review. Med. Mycol. 2012, 50, 337-345.

(49) Guo, X. W.; Li, K.; Sun, Y. N.; Zhang, L. H.; Hu, X. X.; Xie, H. G. Allelopathic effects and identification of allelochemicals in grape root exudates. Acta Hortic. Sin. 2010, 37, 861-868.

(50) Einhellig, F. A.; Rasmussen, J. A. Synergistic inhibitory effects of vanillic and $p$-hydroxybenzoic acids on radish and grain sorghum. $J$. Chem. Ecol. 1978, 4, 425-436.

(51) Yu, J. Q.; Matsui, Y. Phytotoxic substances in root exudates of cucumber (Cucumis sativus L.). J. Chem. Ecol. 1994, 20, 21-31.

(52) Andolfi, A.; Boari, A.; Evidente, M.; Cimmino, A.; Vurro, M.; Ash, G.; Evidente, A. Gulypyrones A and B and Phomentrioloxins B and $\mathrm{C}$ produced by Diaporthe gulyae, a potential mycoherbicide for saffron thistle (Carthamus lanatus). J. Nat. Prod. 2015, 78, 623-629.

(53) Baghestani, A.; Lemieux, C.; Leroux, G. D.; Baziramakenga, R.; Simard, R. R. Determination of allelochemicals in spring cereal cultivars of different competitiveness. Weed Sci. 1999, 498-504.

(54) Bravo, H. R.; Copaja, S. V.; Lamborot, M. Phytotoxicity of Phenolic Acids From Cereals. In Herbicides-Advances in Research; Price, A. J., Kelton, J. A., Eds.; INTECH: 2013; Chapter 3. DOI: $10.5772 / 55942$.

(55) Chong, K. P.; Rossall, S.; Atong, M. In vitro antimicrobial activity and fungitoxicity of syringic acid, caffeic acid and 4hydroxybenzoic acid against Ganoderma boninense. J. Agric. Sci. 2009, $1,15$.

(56) Amborabé, B. E.; Fleurat-Lessard, P.; Bonmort, J.; Roustan, J. P.; Roblin, G. Effects of eutypine, a toxin from Eutypa lata, on plant cell plasma membrane: possible subsequent implication in disease development. Plant Physiol. Biochem. 2011, 39, 51-58.

(57) Matsuura, H.; Nakamori, K.; Omer, E. A.; Hatakeyama, C.; Yoshihara, T.; Ichihara, A. Three lasiodiplodins from Lasiodiplodia theobromae IFO 31059. Phytochemistry 1998, 49, 579-584. 